\title{
Antinociceptive and Anti-Inflammatory Activities of the Aqueous Leaf Extract of Tamarindus indica L. in Albino Rats
}

\author{
S. T. Akor ${ }^{1}$, B. Wampana ${ }^{2} \&$ O. A. Sodipo ${ }^{3}$ \\ ${ }^{1}$ Department of Pharmacology and Toxicology, Faculty of Pharmacy, University of Maiduguri, Maiduguri, \\ Borno State, Nigeria \\ 2 Department of Physiology, Pharmacology and Biochemistry Laboratory, Faculty of Veterinary Medicine, \\ University of Maiduguri, Maiduguri, Borno State, Nigeria \\ ${ }^{3}$ Department of Pharmacology and Therapeutics, College of Medical Sciences, University of Maiduguri, \\ Maiduguri, Borno State, Nigeria
}

Correspondence: S. T. Akor, Department of Pharmacology and Toxicology, Faculty of Pharmacy, University of Maiduguri, Maiduguri, Borno State, Nigeria. E-mail: astord007@gmail.com

Received: February 20, 2015 Accepted: April 9, 2015 Online Published: April 17, 2015

doi:10.5539/jps.v4n2p44 URL: http://dx.doi.org/10.5539/jps.v4n2p44

\begin{abstract}
The research was conducted to investigate the phytochemical constituents, acute toxicity, the anti-inflammatory and antinociceptive activities of the aqueous extract of Tamarindus indica L. (AQETI) leaves. Phytochemical constituents present in AQETI were found to be flavonoids, cardiac glycosides, tannins and terpenoids which might be responsible for the established anti-inflammatory and antinociceptive activities in the plant extract. The leaf extract of the plant was found to be moderately toxic with an intraperitoneal acute toxicity (i.p. $\mathrm{LD}_{50}$ ) of 566 $\mathrm{mg} / \mathrm{kg}$. AQETI produced significant $(\mathrm{p}<0.05)$ and dose-dependent anti-inflammatory and antinociceptive activities. AQETI $(400 \mathrm{mg} / \mathrm{kg})$ exhibited a maximum percentage inhibition $(56.97 \%)$ in acetic acid-induced writhing response and at $30 \mathrm{~min}$ increased the pain threshold by $100 \%$ in the tail immersion test. In the hot plate method, AQETI $(400 \mathrm{mg} / \mathrm{kg})$ showed a similar percentage inhibition $(84.62 \%)$ at 30 and $60 \mathrm{~min}$. The results demonstrate that the aqueous extract of Tamarindus indica L. leaves contains some pharmacologically active substances, was moderately toxic and possessed significant anti-inflammatory and antinociceptive acivities.
\end{abstract}

Keywords: Tamarindus indica, anti-inflammatory, antinociceptive, acetic acid, thermal nociception, tail immersion

\section{Introduction}

Plants are very important in many parts of the world since creation of mankind and have been used by man as source of food, medicine, shelter, clothing, cosmetics, flavours and spices (Gamaniel, 2000; Cordell, 2006; Tor-Anyiin et al., 2006). The use of medicinal plants in West Africa is probably as old as the duration of human settlement in the region (Abdulrahman et al., 2010).

Tamarind or Tamarindus indica L. of the Fabaceae, is an important food in the tropics. It is a multipurpose tree of which almost every part finds at least some use (Kumar \& Bhattacharya, 2008), either nutritional or medicinal. Tamarind is indigenous to tropical Africa but it has been introduced and naturalized worldwide in over 50 countries. The major production areas are in the Asian countries (India and Thailand, Bangladesh, Sri Lanka and Indonesia). In America, Mexico and Costa Rica are the biggest producers. Africa on the whole does not produce tamarind on a commercial scale, though it is widely used by the local people. Minor producing countries in Africa are Senegal, Gambia, Kenya, Tanzania and Zambia (El-Siddig et al., 2006). The plant is well known in traditional medicine (Morton, 1987; El-Siddig et al., 2006; Sidhuraju, 2007) and has been utilized as remedy for a number of ailments (Rimbau et al., 1999; Kristensen and Balslev, 2003; El-Siddig et al., 2006) for its antioxidant (Perez et al., 1995; Ramos et al., 2003; Tsuda et al., 2004; Sudjaroen et al., 2005; Al-Fatimi et al., 2007; Siddhuraju et al., 2007), antihelminthic (Das et al., 2011), Cytotoxic (Al-Fatimi et al., 2007), laxative (Bhat et al., 1990), analgesic (Dighe et al., 2009; Khalid et al., 2010), antiasthmatic (Tayade et al., 2009), hepatoprotective (Pimple et al., 2007), hypolipidaemic and Weight-Reducing (Jindal et al., 2011), antimicrobial (Meléndez and Capriles, 2006; Al-Fatimi et al., 2007; Warda et al., 2007) anti-diabetic, antihelminthic (El-Siddig 
et al., 2006), hypolipidaemic (Martinello et al., 2006), anti-inflammatory (Useh et al., 2004; Fook et al., 2005) activities.

Inflammation is the local response of living mammalian tissues to injury due to any agent. It is the body's defense reaction in order to eliminate or limit the spread of injurious agents as well as to remove the consequent necrosed cells and tissue (Anupama et al., 2012). It is a manifestation of the body's response to tissue damage and infection. The result of each inflammatory reaction may be beneficial (defends the body against agents deranging its homeostasis) or harmful (damage surrounding tissues) (Reynold, 1993). It is part of a multifaceted biological phenomena of vascular tissues to injurious stimuli due to pathogens, injured cells or irritants. It is a defensive attempt by the organism to remove such injurious stimuli and commence the healing process (Maldini et al., 2008), but the symptoms like swelling, tightness, joint pain and irritation associated with inflammation cause patients discomfort. Combating the inflammation can improve circulation and aid healing as well as lessen pain.

Pain is an unpleasant feeling often associated with tissue damage. Tissue injury is the immediate cause of pain as it releases different chemical mediators like prostaglandins, bradykinins and substance $\mathrm{P}$ which act on the nociceptors causing this sensation. The nociceptive stimulus is transmitted to the CNS by small myelinated A $\delta$ fibres or by unmyelinated thin C-fibres (Otsuka \& Yanagisawa, 1990). It is often classified as chronic and acute. Acute pain may be characterized by its quick onset and short duration, lasting for hours. On the other hand, chronic pain is often associated with persistent pain over a large period of time (Merskey \& Bogduk, 1994; Mark, 1999). Pain and fever are the most common complaints associated with inflammation. The NSAIDs used in the inflammatory conditions do not cure and remove the underlying cause of the disease but they only modify the inflammatory response to the disease. Large numbers of NSAIDs are available in the market with their advantages and disadvantages. Though there are standard drugs like Aspirin, Indomethacin, Phenylbutazone, etc., these drugs are not entirely free of side effects and have their own limitation (Reynold, 1993). Thus, there is still a need to develop newer and safer anti-inflammatory drugs. NSAIDs use is frequently limited by gastrointestinal side effects, ranging from dyspepsia to life threatening bleeding from ulceration. It is believed that NSAIDs by inhibiting cyclooxygenase (COX) pathway causes inhibition of prostaglandins synthesis, which are responsible for maintaining gastric mucosal integrity (Kalra et al., 2010). Herbal medicines used in Ayurveda remain the major source of health care for the world's population. The World Health Organisation (WHO) has recognized herbal medicine as an essential building block for primary health care of many countries like India, China and African countries.

Conventional medicines such as steroids and non-steroidal anti-inflammatory drugs (NSAIDs) have shown only limited achievement against all forms of inflammatory circumstances. Furthermore, the unpleasant (adverse) side effects associated with NSAIDs such as bleeding and mucosal damage and other gastrointestinal disturbances as well as tolerance and dependence induced by opiates, the use of these drugs as analgesic agents have not been successful in all the cases making the treatment difficult (Goldsby et al., 2003; Ukwuani \& Hassan, 2014).

Considering the probable adverse effects of these drugs, as well as their limited ability to provide long-term remission, there is a need for a new, safe and cost-effective anti-inflammatory agent which can reduce pain and other associated symptoms (Fleischman et al., 2004). To overcome all these problems, preparations from plant origin have become important in modern medicine and are widely prescribed in traditional systems. Anti-inflammatory and antinociceptive effects in rats may be induced by acetic acid, hot plate (thermal nociception), tail immersion, tail flick or carrageenan hind-paw oedema. In view of the reported uses of this plant and its economic value, the present study investigated the safety and the anti-inflammatory and antinociceptive effects of the aqueous leaf extract of Tamaridus indica L. in rats (Wistar strain albino rats).

\section{Materials and Methods}

\subsection{Plant Collection and Identification}

Fresh sample of the leaves of Tamarindus indica L. were collected from the tamarind population in the University of Maiduguri Campus, Maiduguri, Borno State, in March, 2014. The fresh plant material was taken to the Department of Biological Sciences, University of Maiduguri, where it was identified and authenticated by a plant Taxonomist, Prof. S.S. Sanusi of the same Department.

\subsection{Extraction}

The identified leaves of Tamarindus indica L. were carefully detached from the stalks, washed with distilled water (to remove sand particles) and air-dried (away from sun, dust and intense heat) under the shade in the Pharmacology and Toxicology Laboratory, Faculty of Pharmacy, University of Maiduguri, for one week. The 
leaves were then pulverized using a wooden mortar and pestle to powder, weighed and stored in a specimen bottle. Two hundred and fifty gram of the pulverized leaves of was refluxed (hot extraction) exhaustively with freshly distilled water at $80^{\circ} \mathrm{C}$. The aqueous extract was filtered, concentrated in vacuo and stored in a specimen bottle for use throughout the study. The yield was $62.17 \mathrm{~g}(24.87 \%)$ with respect to the starting material with a light brown colour, fine texture and characteristic taste and odour.

\subsection{Animals}

Fifty three healthy adult Wistar strain albino rats of both sexes weighing 96-193 g and 20 healthy adult mice of both sexes weighing 20-36 g purchased from the Faculty of Pharmacy Animal House were housed in standard wire meshed plastic cages in the Department of Physiology, Pharmacology and Biochemistry Laboratory, Faculty of Veterinary Medicine, University of Maiduguri. The animals were allowed to acclimatize to this environment for a period of two weeks where they were allowed access to food (Vital ${ }^{\circledR}$ Feed) and water $a d$ libitum. All the animals were handled according to the International Guiding Principles for Biomedical Research Involving Animals (CIOMS, 1985) as certified by the Animal Ethics Committee of the Faculty of Veterinary Medicine, University of Maiduguri.

\subsection{Preliminary Phytochemical Screening of AQETI}

Qualitative phytochemical tests were carried out to determine the presence or absence of some pharmacologically active secondary metabolites in the leaves of Tamarindus indica L. using standard methods (Brain \& Turner, 1975; Vishnoi, 1979; Markham, 1982; Silva et al., 1998; Sofowora, 2008; Evans, 2009).

\subsection{Acute Toxicity Studies ( $L D_{50}$ Determination)}

The acute toxicity AQETI was determined as described by Lorke (1983). The experiment was divided in two phases both using the intraperitoneal route of adminisration (i.p) as follows:

\section{Phase I}

Nine (9) healthy Wistar strain albino rats of both sexes weighing 103-168 g were randomly selected and divided into three groups (labelled A, B and C) of three animals each. The animals in each group were weighed and labelled with picric acid on either the head, back or tail (as required), as a mark of identification. The groups were then treated respectively with the extract at incremental doses of $10 \mathrm{mg} / \mathrm{kg}, 100 \mathrm{mg} / \mathrm{kg}$ and $1000 \mathrm{mg} / \mathrm{kg}$ intraperitoneally. The animals were then observed for 24 hours for signs of toxicity and mortality.

\section{Phase II}

Four (4) randomly selected healthy Wistar strain albino rats weighing 109-193 g were grouped into four groups $\mathrm{A}, \mathrm{B}, \mathrm{C}$ and $\mathrm{D}$ of one animal each, weighed and given identification marks. The animals were then exposed to graded doses of AQETI intraperitoneally $(200 \mathrm{mg} / \mathrm{kg}, 400 \mathrm{mg} / \mathrm{kg}, 800 \mathrm{mg} / \mathrm{kg}$ and $800 \mathrm{mg} / \mathrm{kg}$ ) respectively based on the result of phase I. The rats were allowed access to food and water ad libitum and were observed for 24 hours for signs of toxicity and death after which the $\mathrm{LD}_{50}$ was calculated using the formula below:

$$
\operatorname{LD} 50=\sqrt{\mathrm{a} \times \mathrm{b}}
$$

Where $\mathrm{a}=$ lowest dose that kills an animal, $1 / 1$

$\mathrm{b}=$ highest dose that does not kill any animal, 0/1 (Lorke, 1983).

\subsection{Acetic Acid-induced Writhing Test in Mice}

This was carried out according to the method described by Koster et al. (1959); Singh and Majundar (1995). Twenty adult mice of both sexes (weighing between 20 and $36 \mathrm{~g}$ ) were randomly separated into four groups (A, $\mathrm{B}, \mathrm{C}$ and D) of five mice each. They were deprived of food for $24 \mathrm{hr}$ before the commencement of the experiment. Those in group A received distilled water $(3 \mathrm{ml} / \mathrm{kg})$ to serve as negative control group while those in groups B and C received 200 and $400 \mathrm{mg} / \mathrm{kg}$ respectively of the AQETI; while those in group D received pentazocine $(30 \mathrm{mg} / \mathrm{kg})$ to serve as the positive control group. All drug and extract administration were carried out intraperitoneally (i.p). Twenty minutes later, $10 \mathrm{ml} / \mathrm{kg}$ of $0.6 \%$ acetic acid solution (in $0.9 \% \mathrm{w} / \mathrm{v}$ normal saline) was administered i.p. to all groups to induce writhing. Writhing response was observed as described by Turner (1965). The number of writhes was counted from five minutes after acetic acid administration for thirty minutes. A reduction in the number of writhing as compared with the negative control group was considered as evidence of analgesia. The percentage protection was obtained using the formula described by Hernandez-Perez et al. (1995) as shown below; 


$$
\% \text { inhibition }=\frac{\text { Mean no. of writhes in negative control group }- \text { Mean no. of writhes in test group }}{\text { Mean no. of writhes in negative control group }} \times 100
$$

\subsection{Tail Immersion Test}

The tail immersion method was used to evaluate the central mechanism of analgesic activity (Ramabadran et al., 1989).This was based on the method described by Singh and Majundar (1995). Twenty rats of both sexes (weighing between 96-159 g) were randomly divided into four groups (A, B, C and D) of five rats each. They were deprived of food for $24 \mathrm{hr}$ before the commencement of the experiment. Those in group A (negative control) received distilled water $(10 \mathrm{ml} / \mathrm{kg}$ ) while those in groups $\mathrm{B}$ and C received 200 and $400 \mathrm{mg} / \mathrm{kg}$ respectively of AQETI whilst those in group D (positive control) received pentazocine $(30 \mathrm{mg} / \mathrm{kg}$ ). All treatments were by i.p route. Thirty minutes later, the tail (upto $10 \mathrm{~cm}$ ) was dipped into a water bath maintained at $55 \pm 0.5^{\circ} \mathrm{C}$. The time (in seconds) to withdraw the tail clearly out of the water was taken as the reaction time. The latent period of the tail response was determined at 30, 60, 90 and $120 \mathrm{~min}$ after the administration of drugs and extract. The percentage (\%) increase in pain threshold (latency) was calculated by the formula below;

$$
\begin{aligned}
& \% \text { increase pain threshold } \\
& =\frac{\text { Mean reaction time in rats in test group }- \text { Mean reaction time in rats in negative control group }}{\text { Mean Reaction time in rats in negative control group }} \times 100
\end{aligned}
$$

\subsection{Hot Plate (Thermal Nociception) Test}

This was carried out according to the method described by Badilla et al. (2003). Twenty rats of both sexes (weighing between 121-161 g) were randomly divided into four groups (A, B, C and D) of five rats each. They were deprived of food for $24 \mathrm{hr}$ before the commencement of the experiment. Those in group A (negative control) received distilled water $(10 \mathrm{ml} / \mathrm{kg}$ ) while those in groups $B$ and C received 200 and $400 \mathrm{mg} / \mathrm{kg}$ respectively of AQETI whilst those in group D (positive control) received pentazocine $(30 \mathrm{mg} / \mathrm{kg}$ ). All treatments were by i.p route. Thirty minutes later, they were placed on Eddy's hot plate maintained at $55 \pm 0.5^{\circ} \mathrm{C}$. This was repeated every thirty minutes for $2 \mathrm{hrs}$. The reaction time was taken as the time for the rats to jump out of the stainless steel plate on the hot plate. The percentage (\%) inhibition was calculated by the formula below;

$$
\% \text { inhibition }
$$

$=\frac{\text { Mean reaction time in rats in test group }- \text { Mean reaction time in rats in negative control group }}{\text { Mean reaction time in rats in negative control group }} \times 100$

\subsection{Statistical Analysis}

Data generated during the study were expressed as mean \pm standard deviation (S.D.) and analyzed by one way analysis of variance (ANOVA) using statistical package for Social Sciences windows 16.0 version (SPSS, 2007) and $\mathrm{P}<0.05$ was considered significant.

\section{Results}

\subsection{Phytochemistry}

Phytochemical screening revealed that AQETI contained carbohydrates, cardiac glycosides, flavonoids, steroidal nucleus, tannins, terpenoids, but alkaloids, anthraquinones, saponins and starch were absent (Table 1). 
Table 1. Preliminary phytochemical analysis of the AQETI

\begin{tabular}{|c|c|c|c|c|}
\hline S/No & Constituent & Test & Result & Observation \\
\hline \multirow[t]{3}{*}{1} & Alkaloid & General Test: & & \\
\hline & & (i) Dragendorff's Test & - & No ppt formed \\
\hline & & (ii) Mayer's Test & - & No ppt formed \\
\hline \multirow[t]{3}{*}{2} & Anthraquinones & (i) Free anthraquinones Test: & & \\
\hline & & Borntrager's Test & - & No colour formed \\
\hline & & (ii)Combined AnthraquinonesTest & - & No violet colour formed \\
\hline \multirow[t]{5}{*}{3} & Carbohydrates & (i)General (Molisch's) Test & + & Purple colouration \\
\hline & & (ii) Free Reducing Sugar (Fehling's) Test & - & No colour change \\
\hline & & (iii)CombinedReducing Sugar & - & No colour change \\
\hline & & (iv) Ketosis & - & No colour change \\
\hline & & (v) Pentoses & - & Red colouration \\
\hline \multirow[t]{2}{*}{4} & Cardiac Glycosides & (i)Liebermann-Buchard's Test & + & Bluish-green colouration \\
\hline & & (ii) Salkowski's Test & + & Reddish-brown colouration \\
\hline \multirow[t]{4}{*}{5} & Flavonnoids & (i) Ferric Chloride Test & + & Bluish-green Colouration \\
\hline & & (ii) Lead Ethanoate Test & + & Buff Coloured ppt \\
\hline & & (iii) Shinoda's Test & + & Light-Pink colouration \\
\hline & & (iv) Sodium Chloride Test & - & Yellow colouration \\
\hline 6 & Saponins & Froth test & - & No Foam Formed \\
\hline 7 & Starch & Soluble Starch Test & - & No Dark-blue Colouration \\
\hline 8 & Steroidal Nucleus & Liebermann-Buchard's Test & + & Bluish-green colouration \\
\hline \multirow[t]{2}{*}{9} & Tannins & (i) Ferric Chloride Test & + & Deep Blue-black colouration \\
\hline & & (ii) Lead Ethanoate Test & + & White ppt. Formed \\
\hline 10 & Terpenoids & General Test & + & Violet ppt. formed \\
\hline
\end{tabular}

Key:+= Present; - = Absent.

\subsection{Acute Toxicity $\left(L D_{50}\right)$ Studies of the Aqueous Leaf Extract of Tamarindus indica L.}

The i.p. $\mathrm{LD}_{50}$ was $566 \mathrm{mg} / \mathrm{kg}$ (Table 2).

Table 2. Intraperitoneal Acute Toxicity (LD50) Test of the crude aqueous leaf extract of Tamarindus indica L

\begin{tabular}{lllll}
\hline Phase & No. of Rats & Dose $\mathbf{( m g} / \mathbf{k g})$ & Clinical Sign & Mortality \\
\hline 1 & 3 & 10 & None & $0 / 3$ \\
1 & 3 & 100 & None & $0 / 3$ \\
1 & 3 & 1000 & None & $2 / 3$ \\
2 & 1 & 200 & None & $0 / 1$ \\
2 & 1 & $\mathbf{4 0 0}$ & None & $0 / 1$ \\
2 & 1 & $\mathbf{8 0 0}$ & None & $1 / 1$ \\
2 & 1 & 1600 & None & $1 / 1$ \\
\hline
\end{tabular}

i. p. $\mathrm{LD50}=\sqrt{\mathrm{a} \times \mathrm{b}}=\sqrt{800 \times 400}=566 \mathrm{mg} / \mathrm{kg}$

Where $\mathrm{a}=$ least dose that kills the animal $=1 / 1 ; \mathrm{b}=$ highest dose that does not kill the animal $=0 / 1$ 


\subsection{Acetic Acid-Induced Writhing}

AQETI (200- and $400 \mathrm{mg} / \mathrm{kg}$ ) dose-dependently reduced the number of writhes induced by $0.6 \%$ Acetic Acid Solution. The highest dose $(400 \mathrm{mg} / \mathrm{kg})$ produced a significant $(\mathrm{P}<0.05)$ percentage inhibition of $56.97 \%$ while pentazocine $(30 \mathrm{mg} / \mathrm{kg}$ ) gave $86.63 \%$, a value higher than that of the extract (Table 3$)$.

Table 3. Effect of aqueous leaf extract of Tamarindus indica L. on acetic acid induced writhing in mice

\begin{tabular}{llll}
\hline Group & Dose $(\mathbf{m g} / \mathbf{~ k g})$ & No. of Writhes $(\mathbf{s e c s})$ (Mean \pm S.D) & \% Inhibition \\
\hline A (Distilled Water) & $3 \mathrm{ml}$ & $80.40 \pm 1.14^{\mathrm{a}}$ & - \\
B (AQETI-200) & 200 & $39.60 \pm 0.55^{\mathrm{b}}$ & 50.70 \\
C (AQETI-400) & 400 & $34.60 \pm 0.55^{\mathrm{b}}$ & 56.97 \\
D (Pentazocine) & 30 & $10.75 \pm 0.55^{\mathrm{b}}$ & 86.63 \\
\hline
\end{tabular}

$\mathrm{n}=5=$ Number of rats in each group, A (Distilled water) $=$ Negative control, D (Pentazocine) $=$ Positive control. Means with different superscripts $(b)$ are statistically significant $(\mathrm{p}<0.05)$ among the groups when compared with group A (negative control).

\subsection{Tail Immersion Test}

The aqueous leaf extract of Tamarindus indica L. at the different post-treatment times induced a dose-dependent increase in pain threshold (latency) for removal of tail. The maximum latency, (highest significance, $\mathrm{p}<0.05$ ), irrespective of post-treatment time for the extract at 200 and $400 \mathrm{mg} / \mathrm{kg}$ were $5.60 \pm 0.55$ and $6.40 \pm 0.55 \mathrm{sec}$. respectively compared with a value of $9.40 \pm 0.53$ for pentazocine. Pentazocine produced a greater inhibition compared with the exract $(400 \mathrm{mg} / \mathrm{kg})$ at all post-treatment times. Peak antinociceptive effect for the extract occurred at 30 min. post-treatment (Table 4).

Table 4. Effect of aqueous extract of Tamarindus indica L. on tail immersion test in wister albino rats

\begin{tabular}{|c|c|c|c|c|c|c|c|c|c|}
\hline \multirow{2}{*}{$\begin{array}{r}\text { Treatment } \\
\text { Group }\end{array}$} & \multicolumn{6}{|c|}{ Reaction Time in secs (Mean \pm SD) } & \multirow[b]{2}{*}{$\begin{array}{c}\% \\
\text { Inhibition }\end{array}$} & \multirow[b]{2}{*}{$\begin{array}{c}120 \mathrm{~min} \\
(\mathrm{sec})\end{array}$} & \multirow[b]{2}{*}{$\begin{array}{c}\% \\
\text { Inhibition }\end{array}$} \\
\hline & $\begin{array}{c}\text { Dose } \\
(\mathrm{mg} / \mathrm{kg})\end{array}$ & $\begin{array}{c}30 \mathrm{~min} \\
(\mathrm{sec})\end{array}$ & $\begin{array}{c}\% \\
\text { Inhibition }\end{array}$ & $\begin{array}{c}60 \mathrm{~min} \\
(\mathrm{sec})\end{array}$ & $\begin{array}{c}\% \\
\text { Inhibition }\end{array}$ & $\begin{array}{c}90 \mathrm{~min} \\
(\mathrm{sec})\end{array}$ & & & \\
\hline A (Distilled water) & $10 \mathrm{ml}$ & $3.40 \pm 0.89^{\mathrm{a}}$ & 0.00 & $3.60 \pm 1.14^{\mathrm{a}}$ & 0.00 & $4.20 \pm 0.84^{\mathrm{a}}$ & 0.00 & $3.60 \pm 1.14^{\mathrm{a}}$ & 0.00 \\
\hline B (AQETI-200) & 200 & $5.20 \pm 0.45^{\mathrm{b}}$ & 52.94 & $5.60 \pm 0.55^{b}$ & 55.56 & $5.40 \pm 0.55^{b}$ & 28.57 & $4.40 \pm 0.55^{b}$ & 22.22 \\
\hline C (AQETI-400) & 400 & $6.80 \pm 0.45^{b}$ & 100.00 & $6.40 \pm 0.55^{b}$ & 77.78 & $5.40 \pm 0.55^{b}$ & 28.57 & $4.60 \pm 0.55^{b}$ & 27.78 \\
\hline D (Pentazocine) & 30 & $9.40 \pm 0.55^{b}$ & 176.47 & $9.40 \pm 0.45^{b}$ & 170.50 & $9.40 \pm 0.55^{b}$ & 123.81 & $8.80 \pm 0.55^{b}$ & 144.44 \\
\hline
\end{tabular}

$\mathrm{n}=5=$ Number of rats in each group, A (Distilled water) $=$ Negative control, $\mathrm{D}$ (Pentazocine) $=$ Positive control. Means with different superscripts $(b)$ are statistically significant $(\mathrm{p}<0.05)$ among the groups when compared with group A (negative control).

\subsection{Hot Plate (Thermal Nociception) Test}

Aqueous leaf extract of Tamarindus indica L. $(200-400 \mathrm{mg} / \mathrm{kg})$ dose-dependently significantly $(\mathrm{p}<0.05)$ increased the pain threshold (latency) $30 \mathrm{~min}$ after intraperitoneal administration with a percentage inhibition of 53.85 and $84.62 \%$ respectively administration reaching peak in $60 \mathrm{~min}$. The inhibition produced by the extract was however lower when compared with that of the standard drug, pentazocine which was $138.46 \%$, but it was significant $(\mathrm{P}<0.05)$ (Table 5). It was also observed that the percentage inhibition for both the extract and the drug decreased with time. 
Table 5. Effect of aqueous extract of Tamarindus indica L. on hot plate test in wister albino rats

\begin{tabular}{|c|c|c|c|c|c|c|c|c|c|}
\hline Treatment & & & & & Reaction Tin & ee in seconds & $($ Mean \pm SD $)$ & & \\
\hline Goup & $\begin{array}{c}\text { Dose } \\
(\mathrm{mg} / \mathrm{kg})\end{array}$ & $30 \mathrm{~min}(\mathrm{sec})$ & $\begin{array}{c}\% \text { increase in } \\
\text { pain } \\
\text { threshold }\end{array}$ & $60 \mathrm{~min}(\mathrm{sec})$ & $\begin{array}{c}\% \text { increase in } \\
\text { pain } \\
\text { threshold }\end{array}$ & $90 \mathrm{~min}(\mathrm{sec})$ & $\begin{array}{c}\% \text { increase in } \\
\text { pain } \\
\text { threshold }\end{array}$ & $\begin{array}{c}120 \mathrm{~min} \\
(\mathrm{sec})\end{array}$ & $\begin{array}{l}\% \text { increase in } \\
\text { pain threshold }\end{array}$ \\
\hline A (Distilled water) & $10 \mathrm{ml}$ & $2.60 \pm 0.55^{\mathrm{a}}$ & 0.00 & $2.60 \pm 0.55^{\mathrm{a}}$ & 0.00 & $2.80 \pm 0.45^{\mathrm{a}}$ & 0.00 & $2.80 \pm 0.55^{\mathrm{a}}$ & 0.00 \\
\hline B (AQETI-200) & 200 & $4.00 \pm 0.71^{b}$ & 53.85 & $4.00 \pm 0.71^{b}$ & 53.85 & $4.00 \pm 0.71^{\mathrm{b}}$ & 42.86 & $4.00 \pm 0.71^{b}$ & 42.86 \\
\hline C (AQETI-400) & 400 & $4.80 \pm 0.45^{b}$ & 84.62 & $4.80 \pm 0.84^{b}$ & 84.62 & $4.40 \pm 0.55^{b}$ & 57.14 & $3.80 \pm 0.45^{b}$ & 35.71 \\
\hline D (Pentazocine) & 30.00 & $6.20 \pm 0.45^{b}$ & 138.46 & $6.60 \pm 0.55^{b}$ & 153.85 & $5.60 \pm 0.55^{\mathrm{b}}$ & 100.00 & $4.60 \pm 0.55^{b}$ & 64.29 \\
\hline
\end{tabular}

$\mathrm{n}=5=$ Number of rats in each group, A (Distilled water) $=$ Negative control, D (Pentazocine) $=$ Positive control. Means with different superscripts $(b)$ are statistically significant $(p<0.05)$ among the groups when compared with group A (negative control).

\section{Discussion}

The results of the phytochemical screening revealed that AQETI contained carbohydrates, cardiac glycosides, flavonoids, steroidal nucleus, tannins and terpenoids, while alkaloids, anthraquinones, saponins, and starch were absent. These phytochemicals have been reported to influence physiological activities of the body. The presence of carbohydrates in this plant forms the basis for its wide use as a food source by man and animals.

Cardiac glycosides have strong activity on the heart and some have been used in the treatment of congestive heart failure (CHF). Cardiac glycosides may also have pesticidal properties (Okwute, 1992; Harbone, 1998).

Bioactive compounds such as tannins and flavonoids as found in the extract possess analgesic and anti-inflammatory activities (Ahmad et al., 2005).The profile of polyphenols and flavonoids in Tamarindus indica include proanthocyanidine in various forms likeapigenin, anthocyanin, procyanidine, catechin, epicatechin, along with taxifolin, eriodictyol andnaringenin (Samina et al., 2008). Out of these phytoconstituents, polyphenols and flavonoids have been well known to exhibit anti-inflammatory and antinociceptive action (Loggia et al., 1986; Gonzalez et al., 2007; Rao et al., 2008). Flavonoids have been reported to play a role in analgesic activity primarily by targeting prostaglandins (Rao et al., 1998; Rajnarayan et al., 2001). These flavonoids may interact directly with the prostaglandin system and inhibit the substitute cofactor for the prostaglandin generation and also inhibit arachidonic acid lipoxygenation as well as enzymes involved with inactivation or biotransformation of prostaglandins (Panthong et al., 1989; Recio et al., 1995). Flavonoids are also implicated in having antipyretic, anti-inflammatory and antioxidant properties (Evans, 2009). It has been reported that the seeds of Tamarindus indica have antiulcer, anti-asthmatic, anti-diabetic and antioxidant activity (Pankaj et al., 2011; Nurhanani et al., 2012). Also seeds of Tamarindus indica are rich in phenolic compounds, polymeric tannins and fatty acids, flavonoids, saponins, alkaloids and glycosides (Valko et al., 2006; Boots et al., 2008). Flavonoids, tannins, saponins and alkaloids are responsible for the anti-inflammatory and analgesic activity (Doughari, 2006).

The presence of the steroidal nucleus, the backbone of steroidal agents such as cortisone and prednisolone among others is purported to be responsible for the established anti-inflammatory effect of Tamarindus indica $\mathrm{L}$. (Gonzalez et al., 2007).

Tannins have astringent properties which are important in wound healing (Pondrimoli \& Grazi, 1996). There are also reports on the role of tannins in anti-nociceptive activity (Vanu et al., 2006).

Terpenes are known to have anti-inflammatory properties. The antinociceptive activity observed may also be through the effect of the extract on the inflammatory process.

One or a combination of these compounds detected might be responsible for the established antinociceptive and anti-inflammatory effects.

These phytochemicals together with amino acids, proteins, fatty acids and minerals (macro- and micro-elements) have been reported elsewhere (El-Sidigg et al., 2006; Martinello et al., 2006;) in the whole plant and the leaves in particular. Amino acids are building blocks for proteins and are necessary for the synthesis of endogenous peptides such as enkephalins, endorphins and dynorphins among others, which are endogenous pain modulators released by the body especially during acute inflammation and pain. 
Saponins, though absent in this plant extract, cause haemolysis if given intravenously (Patrick-Iwuanyanwu and Sodipo, 2007). The absence of alkaloids and other constituents and or the differences in constituents found in the literature are likely to be due to differences in genetic strains, stages of maturity at which the plant parts were collected, growing conditions, harvesting and handling techniques as well as to differences in analytical methodologies.

The result of the acute toxicity, i.p. $\mathrm{LD}_{50}$ of $566 \mathrm{mg} / \mathrm{kg}$ shows that the substance is moderately toxic. According to Clarke and Clarke (1977) and Sodipo et al. (2007) any substance whose i.p. LD $_{50}$ in rats falls between 50 and $500 \mathrm{mg} / \mathrm{kg}$ is regarded as toxic, between $500 \mathrm{mg} / \mathrm{kg}$ but less than $1,000 \mathrm{mg} / \mathrm{kg}$ is moderately toxic and greater than $1,000 \mathrm{mg} / \mathrm{kg}$ is non-toxic.

The antinocieptive activity of the crude aqueous extract of Tamarindus indica leaf produced significant graded dose effects in all the three models employed viz; acetic acid-induced writhing, hot plate (thermal nociception) and tail immersion. Writhing induced by chemical substances (e.g. acetic acid, phenylbenzoquinone) injected i.p. are due to sensitization of nociceptors by prostaglandins (Nunez et al., 1997; Yongna et al., 2005) and this test is useful for the evaluation of mild analgesic non-steroidal anti-inflammatory compounds (Eekankopf et al., 1988; Ferreira \& Vane, 1974).

The inhibition of writhing in mice by the aqueous extract suggests a peripheral mechanism of action possibly via inhibition of prostaglandins among several possibilities. Pain sensation in acetic acid-induced writhing method is elicited by triggering localized inflammatory response resulting from the release of free arachidonic acid from tissue phospholipid (Ahmed et al., 2006) via cyclooxygenase (COX), and prostaglandin biosynthesis (Duarte et al., 1988). In other words, the acetic acid induced writhing has been associated with increased level of PGE 2 and $\mathrm{PGF}_{2 \alpha}$ in peritoneal fluids as well as lipoxygenase products (Deraedt et al., 1980). The increase in prostaglandin levels within the peritoneal cavity then enhances inflammatory pain by increasing capillary permeability (Zakaria et al., 2008). The acetic acid induced writhing method has been found effective to evaluate peripherally active analgesics. The agent reducing the number of writhing will render analgesic effect preferably by inhibition of prostaglandin synthesis, a peripheral mechanism of pain inhibition (Duarte et al., 1988; Ferdous et al., 2008). The significant pain reduction of the plant extract might be due to the presence of analgesic principles acting within the prostaglandin pathways (Ukwuani \& Hassan, 2014). The abdominal writhing induced by acetic acid has been reported to be less selective (Collier et al., 1968) and proposed to act indirectly by releasing endogenous mediators stimulating neurons that are sensitive to other drugs such as narcotics and centrally acting agents (Toma et al., 2003). The effect of the extract was however; lower than that of the standard drug, pentazocine, in all the three tests and at the doses used. Peak antinociceptive effect was observed at a dose of 400 $\mathrm{mg} / \mathrm{kg}$ in all the tests. In order to further confirm the antinociceptive effect of the extract, the tail immersion and the hot plate tests were carried out. Thermal nociceptive tests are more sensitive to opioid $\mu$ receptors and non-thermal tests are to opioid $\kappa$ receptors (Abbott \& Young, 1988; Furst et al., 1988). The tail immersion test is considered to be selective for the drugs acting central. It measures the complex response to a non-inflammatory, acute nociceptive input and is one of the models normally used for studying central nociceptive activity (Sabina et al., 2009). The effects of the extract in the tail immersion and hot plate methods confirmed its analgesic action. This goes further to suggest also a central mechanism of action for the extract. It is known that centrally acting analgesic drugs elevate the pain threshold of albino rats towards heat and pressure (Singh \& Majumdar, 1995). In the hot plate and tail immersion experiments, pentazocine's effect as an analgesic has a higher effect than that of the extract. The analgesic superiority is expected, since pentazocine is a narcotic analgesic used to alleviate deep-seated pain (Turner, 1965; Besra et al., 1996). Since there were significant activities recorded in both methods (tail immersion and hot plate), the extract could be said to act both peripherally and centrally in producing analgesia. Noxious stimuli cause release of chemicals such as prostaglandins, decarboxylated amines (histamine and serotonin), there by inducing pain locally (Nunez et al., 1997; Yongna et al., 2005). Peripherally acting analgesics such as non-steroidal anti-inflammatory drugs (NSAIDs) act by inhibiting release of prostaglandins (Wagner et al., 2004; Ngulde, 2010). The centrally acting analgesics such as pentazocine act through their receptors in the central nervous system (CNS) by increasing the threshold response to pain stimuli (Singh and Majumdar, 1995). Opiod analgesics inhibit both peripheral and central mechanisms of pain, while NSAIDs inhibit only peripheral pain (Elisabetsky et al., 1995; Pal et al., 1999).

Goyal et al. (2013) evaluated the analgesic effect of the ethanol extract of Tamarindus indica leaves in experimental rats (Adult Swiss Albino Mice) using the tail immersion method in which they reported significant $(\mathrm{p}<0.05)$ analgesic activity in $30 \mathrm{~min}$ after oral doses of 200 and $400 \mathrm{mg} / \mathrm{kg}$. Similar results have been obtained for the seeds (Anupama et al., 2012) and whole stem (Ukwuani \& Hassan, 2014).

The crude aqueous leaf extract of Tamarindus indica contained many pharmacologically active compounds such 
as flavonoids, terpenoids tannins and cardiac glycosides and some of these may be responsible for the local or central antinociceptive effect.

\section{Conclusion}

In conclusion, the aqueous extract of Tamarindus indica L. is moderately toxic, contained some pharmacologically active constituents (cardiac glycosides, flavonoids, steroidal nucleus, tannins and terpenoids) and possessed analgesic and anti-inflammatory activities purported to be mediated via peripheral (probably through inhibition of prostaglandin synthesis) and central mechanisms. This supports the use of the plant in ethnomedical and folkloric practices in alleviating pain.

\section{Acknowledgements}

The authors are grateful to the Dean, Faculty of Pharmacy, Prof. Issa Marte Hussaini and his wife, Mrs. Hafsat Hussaini for their sponsorship and support throughout the research work. The authors also gratefully acknowledge the technical assistance of Mr. Fine Akawo of Chemistry Department, University of Maiduguri, Maiduguri, Borno State.

\section{References}

Abbott, F., \& Young, S. N. (1988). Effect of 5-hydroxy tryptanin precursors on morphine analgesia in the formalin test. Pharmacol. Biochem. Behav., 31(4), 855-860. http://dx.doi.org/10.1016/0091-3057(88)90395-4

Abdulrahman, F. L., Akan, J. C., Sodipo, O. A., \& Onyeyili, P. A. (2010). Effect of aqueous root-bark extract of Vitex domina sweet on haematological parameters in rats. J. Am. Sci., 6(12), 8-12

Ahmad, R., Shaari, K., Lagis, N. H., Hamzah, A. S., Ismail, N. H., \& Kitayima, M. (2005). Anthraquinones from Hedyotis capitellata. Phytochem., 66, 114-1147. http://dx.doi.org/10.1016/j.phytochem.2005.02.023

Ahmed, F., Hossain, M. H., Rahman, A. A., \& Shahid, I. Z. (2006). Antinociceptive and sedative effects of the bark of Cerberaodollam Gaertn. Orient. Pharm. Exp. Med., 6, 344-348. http://dx.doi.org/10.3742/OPEM.2006.6.4.344

Al-Fatimi, M., Wurster, M., Schröder, G., \& Lindequist, U. (2007). Antioxidant, antimicrobial and cytotoxic activities of selected medicinal plants fromYemen. $J$. Ethnopharmacol., 111, 657-666. http://dx.doi.org/10.1016/j.jep.2007.01.018

Anupama, A. S., Kanchan, S. M., Kishor, N. R., \& Rahul, D. K. (2012). The anti-inflammatory and analgesic activities of Tamarindus indica seeds. Int. J. Pharm. Sci. Drug Res., 4(3), 213-217.

Badilla, B., Arias, A. Y., Mora, G. A., \& Poveda, L. J. (2003). Anti-inflammatory and antinociceptive activities of Loasa spciosa in rats and mice. Fitoterapia, 74, 645-705. http://dx.doi.org/10.1016/S0367-326X(02)00299-X

Besra, S. E., Sharma, R. M., \& Gomis, A. (1996). Anti-inflammtory effect of petroleum extract of the leaves of Lichi chinesis Gearten (Spindaceae). J. Ethnopharmacol., 51, 1-6. http://dx.doi.org/10.1016/0378-8741(96)01440-7

Bhat, R. B., Eterjere, E. O., \& Oladipo, V. T. (1990). Ethnobotanical studies from central Nigeria. J. Ethnobot., 44, 382-390. http://dx.doi.org/10.1007/BF03183923

Boots, A.W., Haenen, G. R., \& Bast, A. (2008). Health effects of quercetin: From antioxidant to nutraceutical. Europ. J. Pharmacol., 585, 325-337. http://dx.doi.org/10.1016/j.ejphar.2008.03.008

Brain, K. R., \& Turner, T. D. (1975). The practical Evaluation of Pharmaceuticals. J. Wright-Scientechnica, 190-191.

CIOMS. (1985). Council for International Organizations of Medical Sessions. International Guiding Principles for Biomedical Research Involving Animal c/o WHO 1211. Geneva, Switzerland. 27.

Clark, E. G. C., \& Clark, M. I. (1977). Verterinary Toxicology. (2nd ed.) (p. 10). New York: Bellaire Tindall.

Collier, H. O. J., Dinneen, L. C., Johnson, C. A., \& Schneide, C. (1968). Abdominal constriction response and its suppression by analgesic drugs in mouse. British. J. Pharmacol., 32, 265-268. http://dx.doi.org/10.1111/j.1476-5381.1968.tb00973.x

Cordelle, G. A. (2000). Biodiversity and Drug Discovery- A symbolic relationship. Phytochemistry, 55, 463-480. http://dx.doi.org/10.1016/S0031-9422(00)00230-2 
Das, S., Dey, M., \& Ghosh, A. K. (2011). Determination of anti-helminthic activity of the leaf and bark extract of Tamarindus indica L. Indian J. Pharmaceut. Sci., 73(1), 104-107. http://dx.doi.org/10.4103/0250-474X.89768

Deraedt, R., Joughney, S., Delevakee, F., \& Falhour, M. (1980). Release of prostaglandin E and F in an algogenic reaction and its inhibition. Eur. J. Pharmacol., 51, 17-24. http://dx.doi.org/10.1016/0014-2999(80)90377-5

Duarte, I. D. G., Nakamura, M., \& Ferreira, S. H. (1988). Participation of the sympathetic system in acetic acid-induced writhing in mice. Braz. J. Med. Biol. Res., 21, 3410343.

Dighe, N. S., Pattan, S. R., Nirmal, S. A., Kalkotwar, R. S., Gaware, V. M., \& Hole, M. B. (2009). Analgesic activity of Tamarindus indica. Res. J. Pharmacogn. Phytochem., 2, 69-71.

Doughari, J. H. (2006). Antimicrobial activity of Tamarandus indica L. Trop. J. Pharmaceut. Res., 5, 597-603.

Eerkenkopf, J. W., \& Waionmann, B. M. (1988). Production of prostaglandins in mice following intraperitoneal injection of acetic acid, phenylbenzoquinone and zymosan: its role in the writhing response. Prostaglandins. 36, 698-709.

Elisabetsky, E., Amador, T. A., Albuquerque, R. R., Nunes, D. S., \& Cavalho, A. C. T. (1995). Analgesic activity of psychotria colorata (Wild ex R and S).muell arg. Alkaloids. J. Ethnopharmacol., 48, 77-83. http://dx.doi.org/10.1016/0378-8741(95)01287-N

El-Siddig, K., Gunasena, H. P., Prasa, B. A., Pushpakumara, D. K., Ramana, K. V., Vijayan, P., \& Williams, J. T. (2006). Tamarind-Tamarindus indica L. Fruits for the Future. Southampton Centre for Underutilized crops, RPM printand design, W. Sussex. 1st ed. England: Southampton, UK, p. 188.

Evans, W. C. (2009). Textbook of Pharmacognosy (14th edition). Saunders, W.B. Company Led, 24-28 Oval Road, London NWI 7DX, UK and Printed by Harcourt, B., and Company Asia Pte Led 583 Orchard Road No. 09-01, Forum Singapore, 238884. pp. 13-53, 117-139, 227, 293-334, 471-511.

Ferdous, M., Rouf, R., Shilpi, J. A., \& Uddin, S. J. (2008). Antinociceptive activity of the ethanolic extract of Ficus racemosa Linn. (Moraceae) Orient. Pharm. Exp. Med., 8, 93-96. http://dx.doi.org/10.3742/OPEM.2008.8.1.093

Ferreira, S. H., \& Vane, J. P. (1974). New aspect on the mode of action of non-steroidal anti-inflammatory drugs. Ann.Rez.Pharmacol., 14, 57-73. http://dx.doi.org/10.1146/annurev.pa.14.040174.000421

Fleischman, R. Stern, R., \& Iqbal, I. (2004). Anakinra: an inhibitor of IL-1 for the treatment of Rheumatoid arthritis. J. Expertopin. Biolog. Therapy., 4, 1333-1344. http://dx.doi.org/10.1517/14712598.4.8.1333

Fook, J. M., Macedo, L. L., Moura, G. E., Teixeira, F. M., Oliveira, A. S., Queiroz, A. F., \& Sales, M. P. (2005). A serine proteinase inhibitor isolated from Tamarindus indica seeds and its effects on the release of human neutrophil elastase. J. Life Sci., 76, 2881-2891. http://dx.doi.org/10.1016/j.lfs.2004.10.053

Furst, S., Gyires, K., \& Knoll, J. (1988). Analgesic profile of rimazolium as compared to different classes of painkillers. Drug Res., 4, 552-557.

Gamaniel, K. J. (2000). Toxicity from medicinal plants and their products. Nig. J. Nat. Prod. Medi., 4, 4-7. http://dx.doi.org/10.4314/njnpm.v4i1.11729

Goldsby, R. A., Kindt, T. J., Osborne, B. A., \& Kuby, J. (2003). Immunology (5th Ed, pp. 428-434). New York: WH Freeman and Company.

Gonzalez, G. J., Sanchez, C. S., \& Tunon, M. J. (2007). Anti-inflammatory properties of dietary flavonoids. NutrHosp., 22, 287-293.

Goyal. B., Shashi, A., Jain, S. K., \& Verma, A. (2013). Evaluation of Analgesic activity of Ethanolic extract of Tamarindus indica leaves. on experimental Animal model. Int. J. Pharm. Sci. Res., 4(5), 1994-1997.

Harbone, J. B. (1998). Phytochemcal Methods: A Guide to Modern Techniques of Plant Analysis (pp. 95-99). London: Chapman and Hall.

Hernández-Pérez, M., Rabanal Gallego, R. M., Camandela-Torre, M., \& Rodriguez, B. (1995). Analgesic, anti-inflammatory, antipyretic and haematological effects of aethiopinone, an O-naphthoquinone diterpenoid from Sativa aethiopis roots and two hemisynthetic derivatives. Planta Medica., 61, 505-509. http://dx.doi.org/10.1055/s-2006-959358

Jindal, V., Dinghra, D., Sharma, S., Parle, M., \& Harna, R. K. (2011). Hypolipidaemic and weight-reducing activity of the ethanolic extract of Tamarindus indica fruit pulp in cafeteria diet- and sulpiride-induced 
obese rats. J. Pharmacol. Pharmacother., 2(2), 80-84. http://dx.doi.org/10.4103/0976-500X.81896

Kalra, B., Chaturvedi, S., \& Tayal, V. (2010). Evaluation of gastric tolerability, antinoceptive and anti-inflamm atory activity of combination NSAIDs in rats. J. Pub. Med., 7, 210-212.

Khalid, S., Mossadeq, W. M., Israf, D. A., Hashim, P., Rejaf, S., \& Shaberi, A. M. (2010). In vivo analgesic effect of aqueous extract of Tamarindus indica L. fruits. Med.Princ. Pract., 19(4), 255-259. http://dx.doi.org/10.1159/000312710

Koster, R., Anderson, M., \& DeBeer, E. J. (1959). Acetic acid analgesic screening. Federation Proceed., 18, 418-420.

Kristensen, M., \& Balslev, H. (2003). Perceptions, Use and availability of woody plants among the Gourounsi in Burkina Faso. Biodivers. Conserv., 12, 1715-1739. http://dx.doi.org/10.1023/A:1023614816878

Kumar, C. S., \& Bhattacharya, S. (2008). Tamarind Seed: Properties, Processing and Utilization. Critical Rev. Food Sci. Nutri., 48, 11-20. http://dx.doi.org/10.1080/10408390600948600

Loggia, D. R., Tubaro, A., Dri, P., Zilli, C., \& Del Negro, P. (1986). The role of flavonoids in the anti-inflammatory activity of Chamomilla recutita. Prog. Clin. Biol. Res., 213, 481-448.

Lorke, D. (1983). A new approach to practical acute toxicity testing. Arch. Toxicol., 54, 275-287. http://dx.doi.org/10.1007/BF01234480

Maldini, M., Sosa, S., Montoro, P., Gingaspero, A., Balik, M. J., Pizza, C., \& Loggia, R. D. (2008). Screening of the topical anti-inflammatory activity of the bark of Acacia cognifera willd, Byrsonina crassifolia Kunth, Sweetia panamensis Yakovlev. and the leaves of Sphagneticola trilobata Hitchcock. J. Pub. Med., 122, 430-433.

Mark, J. M. (1999). The induction of pain: an integrative review. Progress in Neurobiol, 57, 161-164.

Markham, K. R. (1982). Technique of Flavonoids Identification (pp. 1-113). New York, USA: Academic Press.

Martinello, F., Soares, S. M., Franco, J. J., Santos, A. C., Sugohara, A., Garcia, S. B., ... Uyemura, S. A. (2006). Hypolipaemic and antioxidant activities from Tamarindus indica L. pulp fruit extract in hypercholesterolaemic hamsters. J. Food Chem. Toxicol., 44, 810-818. http://dx.doi.org/10.1016/j.fct.2005.10.011

Meléndez, P. A., \& Capriles, V. A. (2006). Antibacterial properties of tropical plants from Puerto Rico. J. Phytomed., 13, 272-276. http://dx.doi.org/10.1016/j.phymed.2004.11.009

Merskey, H., \& Bogduk, N. (1994). Classification of Chronic Pain: Descriptions of Chronic Pain Syndromes and Definitions of Pain Terms (2nd Ed, pp.55-56). Seattle, Washington: IASP Press.

Morton, J. F. (1987). Tamarind. In Fruits of Warm Climates (pp. 115-121). Miami, USA.

Ngulde, S. I. (2010). Toxicological and antinociceptive studies of the aqueous extract of Cassia arereh Del. stem bark in albino rats and mice. M.Sc. Dessertation. University of Maiduguri, Maiduguri, Nigeria.

Nunez, G. M., Emim, J. A., Souccar, C., \& Lapa, A. J. (1997). Analgesic and anti-inflammatory activities of the aqueous extract of Plantago major L. Int. J. Pharmacogn., 35(2), 99-104. http://dx.doi.org/10.1076/phbi.35.2.99.13288

Nurhanani, R., Amirah, F., \& Senthilkumar, S. (2012). Effects of various solvents on the extraction of antioxidant phenolics from the leaves, seeds, veins and skins of Tamarindus indica L. Food Chem., 132, 441-448.

Okwute, S. K. (1992). Plant derived pesticidal and antimicrobial agents for use in Agriculture: A review of phytochemical and biological studies on some Nigerian plants. J. Agric. Tech., 2(1), 62-70.

Otsuka, M., \& Yanagisawa, M. (1990). Pain and neurotransmitters. Cell Mol. Neurobiol., 10(3), 293-302. http://dx.doi.org/10.1007/BF00711176

Pal, S., Sen, T., \& Chaudhuri, A. K. (1999). Neuropsychopharmacological profile of the methanolic fraction of Bryophyllum pinnatum leaf extract. J. Pharm. Pharmacol., 51, 313-318. http://dx.doi.org/10.1211/0022357991772312

Pankaj, K., Sunil, S., \& Suresh, K. (2011). Antiulcer effect of methanolic extract of Tamarindus indica L. seeds in different experimental models. J. Pharm. Bioallied Sci., $3,236$. http://dx.doi.org/10.4103/0975-7406.80778 
Panthong, A., Tassaneeyakul, W., Kanjanapothi, D., Tantiwachwuttikul, P., \& Reutrakul, V. (1989). Anti-inflammatory activity of 5,7 dimethoxy-flavon. Planta Med., 55, 133-136. http://dx.doi.org/10.1055/s-2006-961905

Patrick-Iwuanyanwu, K. C., \& Sodipo, O. A. (2007). Studies on saponins of the leaf of Clerodendron thomsonae Balfour. Acta Biologica Szegediensis, 5(12), 117-123.

Perez, R. M., Perez, S., Zavala, M. A., \& Salazar, M. (1995). Anti-inflammatory activity of the bark of Hippocratea excelsa .J. Ethnopharmacol., 47, 85-90. http://dx.doi.org/10.1016/0378-8741(95)01257-E

Pimple, B. P., Kadam, P. V., Badgujar, N. S., Bafina, A. R., \& Patil, M. J. (2007). Protective effect of Tamarindus indica L. against Paracetamol induced-hepatotoxity in rats. Ind. J. Pharm. Sci., 69(6), 827-831. http://dx.doi.org/10.4103/0250-474X.39445

Pondrimoli, E., \& Grazi, A. (1996). A method of assaying liver hexose monophosphate oxidation. $J$. Comprehensive Biochem., 17, 163-187. http://dx.doi.org/10.1016/B978-0-444-40695-8.50013-0

Ramabadran, K., Bansinath, M., Turndorf, H., \& Puig, M. M. (1989). Tail immersion test for the evaluation ofa nociceptive reaction in mice; methodological considerations. J. Pharmacol. Toxicol. Methods, 21, 21-31. http://dx.doi.org/10.1016/0160-5402(89)90019-3

Rajnarayan, K., Reddy, M. S., Chaluvadi, M. R., \& Krishna, D. R. (2001). Biflavonoids classification, pharmacological, biochemical effects and therapeutic potential. Indian J. Pharmacol., 33, 2-16.

Ramos, A., Visozo, A., Piloto, J., Garcia, A., Rodriguez, C. A., \& Rivero, R. (2003). Screening of antimutagenicity via antioxidant activity in Cuban medicinal plants. J. Ethnopharmacol., 87, 241-246. http://dx.doi.org/10.1016/S0378-8741(03)00156-9

Rao, M. R., Rao, Y. M., Rao, A. V., Prabhkar, M. C., Rao, C. S., \& Muralidhar, N. (1998). Antinociceptive and anti- inflammatory activity of a flavonoid isolated from Caralluma attenuate. J. Ethnopharmacol., 62, 63-66. http://dx.doi.org/10.1016/S0378-8741(98)00048-8

Rao, Y. K., Fang, S. H., \& Tzeng, Y. M. (2008). Antiinflammatory activities of flavonoids and a triterpenecaffeate isolated from Bauhinia variegate. Phytother. Res., J. Pub. Med., 22, 957-962. http://dx.doi.org/10.1002/ptr.2448

Recio, M. C., Giner, R. M., Manes, S., Talens, A., Gubells, L., \& Gueho, J. (1995). Anti-flammatory activity offlavonol glycosides from Erythrospermum monticolum depending on single or repeated local TPA administration. Planta Medica, 61, 502-504. http://dx.doi.org/10.1055/s-2006-959357

Reynold, J. E. F. (1993). Analgesic and anti-inflammatory agents: In: Martindale. The Extra Pharmacopoiea, 30th Edn. London: Pharmacological Press. p. 1.

Rimbau, V., Cerdan, C., Vila, R., \& Iglesias, J. (1999). Anti-inflammatory Activity of some extracts from plants used in the traditional medicine of North-African countries (II). J. Phytother. Res., 13, 128-132. http://dx.doi.org/10.1002/(SICI)1099-1573(199903)13:2\%3C128::AID-PTR399\%3E3.0.CO;2-7

Sabina, E. P., Chandel, S., \& Rasool, M. K. (2009). Evaluation of analgesic, antipyretic and ulcerogenic effect of Withaferin A. Int. J. Integrat. Biol., 6(2), 52-56.

Salim, A., Simons, A., Waruhin, A., \& Orwa, C. (1998). Agroforestry Tree Database: Tamarindus indica, a tree species reference and selection guide and tree seed supplier's directory Nairobi, Kenya: ICRAF-International Council for Research in Agroforestry.

Samina, K .K., Shaikh, W., \& Shahzadi, S. (2008). Chemical constituents of Tamarindus indica medicinal plant in Sindh. Pak. J. Bot., 40, 2553-2559.

Siddhuraju, P. (2007). Antioxidant activity of polyphenolic compounds extracted from defatted raw and dry heated Tamarindus indica seed coat. LWT, 40, 982-990. http://dx.doi.org/10.1016/j.lwt.2006.07.010

Silva, L. G., Lee, I. S., \& Kinnghorn, D. A. (1998). Special Problems with Extraction of Plants in Natural Products Isolation (Cannel, R.J. PED). Humana press Inc. 999, Riverview Drive, suite 208. Totowa, New Jersey, USA 072512. pp.343-364. http://dx.doi.org/10.1007/978-1-59259-256-2_12

Singh, S., \& Majumdar, D. K. (1995). Analgesic activity of Ocimum sanctum and its possible mechanism of action. Int. J. Pharmacogn., 33, 188-192. http://dx.doi.org/10.3109/13880209509065361

Sofowora, A. (2008). Medicinal Plants and Traditional Medicines in Africa. (p. 289). Ibadan, Nigeria: Spectrum books Ltd. 
SPSS. (2007). Statistical Package for Social Sciences. Windows Version 16.0. SPSS Chicago, //USA.

Sudjaroen, Y., Haubner, R., Würtele, G., Hull, W. E., Erben, G., Spiegelhalder, B., ... Owen, R. W. (2005). Isolation and structure elucidation of phenolic antioxidants from Tamarind (Tamarindus indica L.) seeds and pericarp. J. Food Chem. Toxicol., 43, 1673-1682. http://dx.doi.org/10.1016/j.fct.2005.05.013

Tayade, P. M., Ghaisas, M. M., Jagtap, S. A., \& Dongre, S. H. (2009). Antiasthmatic activity of methanolic extract of leaves of Tamarindus indica L. J. Pharm. Res., 2, 944-947.

Toma, W., Graciosa, J. S., Hiruma-Lima, C. A., Andrade, F. D., Vilegas, W., \&Souza-Brita, A. R. (2003). Evaluation of the analgesic and antiedematogenic activities of Quassia amara bark extract. J. Ethnopharmacol., 85, 19-23. http://dx.doi.org/10.1016/S0378-8741(02)00334-3

Tor-Anyiin, T. A., Sha'ato, R., \& Oluma, H. O. A. (2006). Phytochemical screening and antibacterial activity of Cissampeo mucronata. A rich extract. J. Pharm. Biores., 3(2), 103-106.

Tsuda, T., Watanabe, M., Ohshima, K., Yamamoto, A., Kawakishi, S., \& Osawa, T. (2004). Antioxidative components isolated from the seed of tamarind (Tamarindus indica L.). J. Agric. Food Chem., 42, 2671-2674. http://dx.doi.org/10.1021/jf00048a004

Turner, R. A. (1965). Screening Methods in Pharmacology (Vol. 1. pp. 105-108). New York: Academy Press. http://dx.doi.org/10.1016/B978-1-4832-3266-9.50022-0

Ukwuani, N. A., \& Hassan, F. F. (2014). Analgesic properties of Tamarindus indica L. stem bark fractions in albino rats. Sky J. Biochem. Res., 3(2), 24-27.

Useh, M. N., Nok, A. J., Ambali, S. F., \& Esievo, K. A. (2004). The inhibition of Clostridium chauvoei (jakari strain) neuramidase activity by ethanolic extracts of the stem barks of Tamarindus indica and Combretum fragrans. J. Enzyme Inhib. Med. Chem., 19, 339-342. http://dx.doi.org/10.1080/14756360409162447

Valko, M., Rhodes, C. J., \& Moncol, J. (2006). Free radicals, metals and antioxidants in oxidative stress-induced cancer, Chemico-Biolog. Interact., 160, 1-40. http://dx.doi.org/10.1016/j.cbi.2005.12.009

Vanu, M. R., Palanivelu, S., \& Panchanatham, S. (2006). Immunomodulatory and anti-inflammatory effects of Semecarpus anacardium Linn. Nut milk extract in experimental inflammatory conditions. Biol. Pharmaceut. Bull., 29, 693-700. http://dx.doi.org/10.1248/bpb.29.693

Vishnoi, N. R. (1979). Advanced Practical Chemistry (pp. 444-449). Ghaziabad-India: Yikas Publication House, Pvt. Ltd.

Wagner, W., Khanna, P., \& Furst, D. E. (2004). Non-steroidal anti-inflammatory drugs, disease modifying antirheumatoid drugs, nonopioid analgesics and drugs used in gout. In B. G. Katzung (Ed). Basic and Clinical Pharmacology (9th ed., p. 577). The Mc Graw-Hill Co. Inc.

Warda, S., Gadir, A., Mohamed, F., \& Bakhiet, A. O. (2007). Antibacterial activity of Tamarindus indica fruit and Piper nigrum. Res. J. Microbiol., 2, 824-830. http://dx.doi.org/10.3923/jm.2007.824.830

Yongna, Z., Wapana, R., Pisit, B., Zhongkun, L., \& Rongpin, Z. (2005). Analgesic and the antipyretic activities of the aqueous extract of Urtica macrorrhiza in experimental animals. Fitoterapia. 75, 91-95. http://dx.doi.org/10.1016/j.fitote.2004.10.018

Zakaria, Z. A., Abdul-Ghani, Z. D. F., Raden, M., Nor, R. N. S., Gopalan, H. K., Sulaiman, M. R., ... Ripin, J. (2008). Antinociceptive, anti-inflammatory, and antipyretic properties of an aqueous extract of Dicranopteris linearis leaves in experimental animal models. J. Nat. Med., 62, 179-187. http://dx.doi.org/10.1007/s11418-007-0224-x

\section{Copyrights}

Copyright for this article is retained by the author(s), with first publication rights granted to the journal.

This is an open-access article distributed under the terms and conditions of the Creative Commons Attribution license (http://creativecommons.org/licenses/by/3.0/). 